\title{
A kvalitatív pedagógiai kutatásmódszertan hazai fejlődéstörténete négy neveléstudományi folyóirat tükrében: fókuszban a 2011-2015 közötti időszak
}

\author{
Sántha Kálmán, * Katona Istvánné** és Subrt Péter ***
}

A tanulmány a magyar kvalitatív pedagógiai kutatásmódszertan fejlődéstörténetét vizsgáló munkák sorába kíván illeszkedni, folytatja a Sántha Kálmán $(2009,2016)$ tanulmányai által megkezdett törekvést. Négy magyar neveléstudományi szaklap, az Iskolakultúra, az Új Pedagógiai Szemle, a Magyar Pedagógia és a Pedagógusképzés 2011 - 2015 megjelent számait vizsgáltuk, célként a jelenlegi hazai kvalitatív pedagógiai kutatásmódszertan helyzetének feltárását, valamint a hazai és a nemzetközi kvalitatív irányzatok közötti kapcsolatok feltérképezését tüztük ki. A tanulmányokat a kombinált (deduktív és induktív) logika szerinti kvalitatív tartalomelemzési eljárással dolgoztuk fel, a szövegkorpuszokat fö- és alkódok hierarchiájával vizsgáltuk. Az eredményeket három nagyobb tartalmi csoport, a kvalitatív tanulmányok elméleti hátterére vonatkozó cikkek, a kvalitatív módszerek alkalmazhatóságát elemző empirikus tanulmányok és a recenziók, konferencia-ismertetök alapján jelenítettük meg. A tanulmány a hazai kvalitatív pedagógiai kutatásmódszertan szisztematizálási törekvéseihez kíván hozzájárulni.

Kulcsszavak: pedagógiai szaklapok, kvalitatív kutatási módszerek, kvalitatív tartalomelemzés

\section{Bevezetés}

A magyar neveléstudományban a 2000-es évek óta egyre intenzívebben jelentek meg a kvalitatív kutatásmódszertan elméleti és gyakorlati elemeire alapozó, vagy azokat továbbgondoló, új kontextusba helyező tanulmányok. Ezek a munkák a kvalitatív módszertani aspektusok továbbgondolása mellett rámutatnak arra is, hogy a kvalitatív vizsgálatok milyen szerepet játszhatnak az iskolai valóság gyakran megismételhetetlen és helyzetfüggő elemeinek interpretálása során. Így egyre többször találkozunk a tanári tevékenység, gondolkodás, reflexió, nézet témakörök mellett az iskolafejlesztés, a hatékonyság növelése esetében is kvalitatív jellegű szemléletmóddal.

\section{Elméleti háttér - problémafelvetés}

A magyar neveléstudomány kutatásmódszertani szemléletét az elmúlt 15 évben intenzív átalakulás jellemezte, a kvalitatív módszertan egyre gyakoribb alkalmazása hozzájárult a pedagógiai problémák sokoldalú vizsgálatához. Vélhetően ez a tendencia a jövőben is érvényesülni fog, hiszen a nemzetközi törekvésekkel összhangban újabban a kombinált módszertan (Mixed Methods) sokoldalú modelljei, vagy akár a QCA-technikák (Qualitative Comparative Analysis) további repertoárbővülést és módszertani kihívásokat eredményezhetnek (Galántai, 2016; Sántha, 2014, 2015).

\footnotetext{
* Pannon Egyetem Neveléstudományi Intézet, egyetemi docens. E-mail: santha.kalman1@gmail.com

** Eszterházy Károly Egyetem Neveléstudományi Doktori Iskola, PhD hallgató. E-mail: rkatonakatona@gmail.com

*** Eszterházy Károly Egyetem Neveléstudományi Doktori Iskola, PhD hallgató. E-mail: subrtpeter6@gmail.com
} 
A hazai kvalitatív kutatásmódszertan fejlődéséről már született összegző munka (Sántha, 2009, 2016). Ez tükrözi azt az utat, amelyen a kvalitatív neveléstudományi módszertani repertoár 2000 és 2010 között végigment. Ekkor négy pedagógiai folyóirat (Iskolakultúra, Magyar Pedagógia, Új Pedagógiai Szemle, Pedagógusképzés) 2000 és 2010 közötti számainak tartalmait tekintettük át. Úgy véljük, hogy elérkezettnek látszik újra az idő arra, hogy a hazai kvalitatív módszertan iránt érdeklődők számára újabb áttekintést végezzünk, és a jelzett folyóiratok 2011 és 2015 közötti kvalitatív jellegű tanulmányait elemezzük. Ezzel, túl azon, hogy aktualizálnánk a magyar neveléstudományi kvalitatív módszertan állapotát, a jelenlegi nemzetközi és hazai kvalitatív módszertani helyzetből kiindulva akár kísérletet is tehetünk a jövő kvalitatív kutatásmódszertani trendjeinek megfogalmazására is. Ismereteink szerint további hazai neveléstudományi szaklapok hasonló jellegű feldolgozása is folyamatban van.

A hazai kvalitatív neveléstudományi módszertani repertoár fejlődéstörténetének vizsgálata során célszerű egyértelműen rögzíteni, hogy milyen kritériumok alapján elemeztük a fejlődést. Kiindulópontként Sántha (2009) hasonló jellegü összegző munkájában használt fejlődéstörténeti fázisokat vettük alapul. Ez a tanulmány többek között rámutatott arra, hogy a magyar neveléstudományban a 2000-es évek elejére tehető a kvalitatív kutatásmódszertan teoretikus és gyakorlati elemeivel kapcsolatos szakirodalom elterjedése. A szakemberek már akkor azt prognosztizálták, hogy a közeljövő magyar kvalitatív neveléstudományi módszertanában kiemelt szerepet kap majd a módszertani háttér erősödése, a különböző kvalitatív technikák empirikus vizsgálatokban történő szisztematikus elterjedése, a számítógéppel támogatott kvalitatív adatelemzés térhódítása, valamint a kombinált módszertannal kapcsolatos igény is fokozatosan beépül a tudományos gondolkodásba. Úgy véljük, hogy több mint öt évvel Sántha (2009) tanulmányának publikálása után a jelzett szempontok aktuálissá válhattak, ezért tanulmányunkban kiemelt figyelmet fordítottunk a vizsgálatukra.

Van néhány alapvető problémakör, amit célszerủ átgondolni a kvalitatív kutatások iránt érdeklődőknek, valamint választ keresni arra a kérdésre, hogy milyen a jelenlegi hazai kvalitatív pedagógiai kutatásmódszertan helyzete, hogyan illeszkedik a hazai tendencia az aktuális nemzetközi irányzatokhoz. Nemzetközi színtéren Corbin „kvalitatív forradalmat" vél felfedezni napjainkban, amely belső forradalomként is értelmezhető, hiszen a kvalitatív módszertan alapvető változásairól szól, felhasználva a legújabb technikai vívmányokat. Napjainkban az angol és német nyelvterületen egyaránt megfigyelhető az új technikák, módszerek létrejötte (lassan ugyanez állítható a spanyol nyelvű kvalitatív kutatásmódszertani szakirodalomról is), fókuszban áll a számítógéppel támogatott kvalitatív adatelemzés, valamint a vizsgálatok szisztematizálására való törekvés. Mindez sokakban azt a félelmet kelti - véleményünk szerint alaptalanul -, hogy a kvalitatív elemzések gépiessé válnak, háttérbe szorul a kutatói kreativitás és a szoftverek eltörlik „a kvalitatív kutatás színpadáról a régi szép idők kulcsfogalmát, az értelmezést" (Corbin és Strauss, 2015. 23.). Keller (2014) úgy véli, hogy napjainkban célszerű lenne átgondolni a "klasszikus" kvalitatív vizsgálatokra vonatkozó nézeteket, melyek sokszor tévútra viszik az ilyen jellegű vizsgálatok iránt érdeklődőket, lásd például a teljesség igénye nélkül az induktivitás, a metodológiai elvek, a számítógéppel támogatott kvalitatív elemzés vagy a szisztematizálási törekvések problémáját. Egyetérthetünk Corbin és Strauss (2015), valamint Keller (2014) megállapításaival, hiszen a szisztematizálási törekvések, ötvözve a modern kor vívmányaival (lásd a szoftverek szerepét a kvalitatív elemzésekben) elvezethetnek oda, hogy a kvalitatív elemzések végleg megszabadulhatnak a „puha tudomány” címkéjétől. 


\section{Módszertani háttér}

\section{Minta, mintavétel}

A tanulmányban az Iskolakultúra, az Új Pedagógiai Szemle, a Magyar Pedagógia és a Pedagógusképzés folyóiratok 2011-2015 közötti számainak teljes vertikumát tekintettük át. A releváns tanulmányok kiválasztásánál arra figyeltünk, hogy a cikkek tartalmazzanak a kvalitatív módszertannal kapcsolatos teoretikus vagy módszertani elemeket. Kétségtelen, hogy a kvalitatív empirikus vizsgálatok esetén gyakran használt fegyelmezett szubjektivitás elvét betartva is probléma, hogy a kiválasztott tanulmányok ( $\mathrm{N}=27$ ) száma akár még bővíthető lett volna annak ellenére, hogy törekedtünk a besorolás szempontjainak rögzítésére (például, ha a szerzők nem jelölték, hogy kvalitatív kutatásról van szó, de alkalmaztak kvalitatív módszereket, akkor ezek a tanulmányok a vizsgálat részeivé váltak). A tanulmányok besorolásának folyamatában több kutató párhuzamos tevékenységével alkalmaztuk a személyi triangulációt, a nem egyértelmű eseteket átgondoltuk és szakmai konszenzus alapján döntöttünk.

\section{Az adatfeldolgozás módja, a kvalitatív tartalomelemzés lépései}

Az adatokat kvalitatív tartalomelemzéssel, a tartalmilag strukturáló elv alapján (Kuckartz, 2012) dolgoztuk fel: a tanulmányokat a kombinált (deduktív és induktív) logika szerinti kvalitatív tartalomelemzési technikával elemeztük, hozzájárulva így az adatvesztés minimalizálásához. A kombinált eljárás során általában viszonylag kevés fő kódrendszerrel indul az elemzés, az alkódok induktív módon, a szövegkorpuszból kerülnek kialakításra.

A deduktív tartalomelemzésnél az elméletből indulunk ki, vagy saját kutatói tapasztalat alapján generált kategóriarendszert használunk, ahol a kategóriákhoz a tanulmányok megfelelő szövegrészleteit társítjuk. Az eljárás során az átfedések kiküszöbölése érdekében a lehető legprecízebben célszerű definiálni a kategóriákat. Az elemzésnél a főkategóriákat az előzetes kutatási tapasztalatnak és az elméleti háttérnek megfelelően alakítottuk ki. Így három nagyobb csoport, a kvalitatív tanulmányok elméleti hátterére vonatkozó cikkek, a kvalitatív módszerek alkalmazhatóságát elemző tanulmányok (empirikus anyagok) és a recenziók, konferencia-ismertetők képezték a főkategóriákat. Ezen a ponton célszerű kitérni arra, hogy a harmadik főkategória értelmezhető-e önálló kategóriaként, vagy pedig azonos tartalmakat fed le az első kettővel. Úgy véljük, hogy feltüntethető önálló kategóriaként, hiszen ebben a széles témakörben a tudományos konferencia-ismertetőket is elemeztük, amelyek ugyan tartalmaznak módszertani elemeket, de műfajukból adódóan nem az első két kategóriának megfelelő mélységben.

Az elemzés során a deduktív logika szerint kódlistát gyártottunk, a priori kódolást használtunk. Az a priori kódolás az adatkódolás olyan formája, ahol a főkategóriákat az elemzés előtt, elméleti megfontolásokból, vagy akár saját tapasztalatból kiindulva állítjuk elő. A kategóriák főkódjai a következőképpen alakultak: a kvalitatív vizsgálatok elméleti hátterével foglalkozó tanulmányok esetén 10 főkóddal dolgoztunk (trianguláció, kvalitatív kutatásmódszertan, kvalitatív adatelemző szoftver, érvényesség, megbízhatóság, multikódolt adatok/kódolás, hermeneutika, fenomenológia, hermeneutika és neveléstudomány, fenomenológia és neveléstudomány), míg a kvalitatív módszerek alkalmazását elemző tanulmányoknál öt főkód képezte a vizsgálat alapját (kutatási módszer, „kvalitatív" kifejezés, trianguláció, mintavétel, számítógéppel támogatott kvalitatív adatelemzés). A recenziókat három tartalmi kategória, a leíró jellegű tartalomismertetés, a mértéktartó és az erős kritika alapján vizsgáltuk. Majd következett a főkódokhoz rendelhető, a kódjelentésekkel azonos tartalmú szövegszegmensek társítása. 
A deduktív logikának megfelelő eljárást a szövegszegmensek mélyrétegeinek induktív módon történő feltárása követte, azaz a szövegrészletekből a főkódokhoz jelentésben illő alkódokat kerestünk. A kvalitatív vizsgálatok elméleti hátterével foglalkozó tanulmányok esetében 65, a kvalitatív módszerek alkalmazását elemző tanulmányoknál 49, míg a recenzióknál 27 alkódot állapítottunk meg (részletesen lásd az eredmények feldolgozásánál).

A kategóriák közötti átfedések kiküszöbölése érdekében a kódolt szövegkorpuszokat két nap után ugyanazon logikai rendszer alapján újrakódoltuk annak érdekében, hogy a még kérdéses kategóriák végső besorolását megtaláljuk. A kódolás megbízhatóságát személyi triangulációval biztosítottuk. Minden tanulmány esetében interkódolást alkalmaztunk, a kódolást két kódoló végezte. A kódolás megbízhatósági indexe magas, átlagban 0,71 .

\section{Az eredmények elemzése}

\section{A kvalitatív kutatásmódszertannal kapcsolatos tanulmányok kvantitatív mutatói}

Az eredmények elemzését a főkategóriák függvényében végezzük, majd részletesen kitérünk az alkategóriák értelmezésére is. A folyóiratokban megjelenő kvalitatív kutatásmódszertannal kapcsolatos tanulmányok kvantitatív mutatóit az 1. táblázatban tekintjük át:

\begin{tabular}{lcccccc} 
& 2011 & 2012 & 2013 & 2014 & 2015 \\
& 3 & 6 & 1 & 4 & 4 \\
Iskolakultúra & 3 & - & - & - & \\
$\begin{array}{l}\text { Új Pedagógiai } \\
\text { Szemle }\end{array}$ & & & & & \\
Magyar Pedagógia & - & - & 1 & - & 3 \\
Pedagógusképzés & - & & 2 & - & - & - \\
\hline
\end{tabular}

Az 1. táblázat alapján a vizsgált időszakban a legtöbb tanulmány az Iskolakultúra oldalain jelent meg. Az Új Pedagógiai Szemle és a Magyar Pedagógia közel azonos számban adott teret kvalitatív jellegű munkáknak. A Pedagógusképzés 2012-2013-as összevont számában két kvalitatív kutatásmódszertanra vonatkozó írást találtunk, melyeket a 2012-es évnél tüntettünk fel. A Magyar Pedagógiában 2013-tól a korábbi évekhez viszonyítva több cikk tartalmaz kvalitatív módszertannal kapcsolatos eredményeket. A kvantitatív mutatók tárgyalásánál fontos megjegyezni, hogy havi és negyedévben megjelenő folyóiratokról van szó, ezért az egyes lapszámokban különböző mennyiségben jelennek meg a neveléstudományt érintő írások.

A kvantitatív elemzést a főkódok szintjeinek és fokszámainak vizsgálatával folytattuk, melyek kiegészítő információkkal szolgálhatnak az ok-okozati összefüggések feltárását célul kitűző mélyrétegű elemzés számára. A kódháló hierarchikus szintjeinek megállapításánál a következő gondolatmenetet követtük: ha nulladik szintnek tekintjük a vizsgált főkódokat, akkor az első szinten találhatók a nulladik szintről egy útvonallal elérhető alkódok, tartalmi csomópontok. Ezt az elvet követve, a második szinten az első szintről egy útvonallal elérhető tar- 
talmi elemek foglalnak helyet, ugyanígy gondolkodhatunk a további szintszámok meghatározásánál is. Fokszámok alatt pedig adott kódból (fogalomból) kiinduló élek számát értjük.

A kvalitatív vizsgálatok filozófiai hátterével foglalkozó cikkekben viszonylag kevés, négy főkód szerepel. Kiemelkedően hangsúlyos a "humán tudományok önállósodási törekvései", valamint a "hermeneutika, fenomenológia és a neveléstudomány kapcsolata" alkódok sokoldalú kifejtése. Alacsonyak a fokszámok is (egy, kettő, öt), a tanulmányok általában kevés témakörre koncentrálnak (például hermeneutikai élményfogalom, hermeneutikai szövegértelmezés, kulturális kontextus).

Az elméleti cikkekben azonos hangsúllyal jelennek meg a vizsgált főkódok. Általában kettő, három vagy négy szinten ábrázolták a szerzők a témákat. Ettől eltérő, öt illetve hat szintet csak a „kódolási folyamat megbízhatósága" alkódnál állapítottunk meg, ez a témakör kiemelkedően hangsúlyos a kutatások folyamatában. A kvalitatív vizsgálatok elméleti hátterével foglalkozó tanulmányok esetében szintén közel azonos fokszámmal rendelkező főkódokat találtunk. Az érvényesség és megbízhatóság főkódokat együtt kezelve 13 alkódot állapíthatunk meg. Az alkódok magas száma a témakörök kidolgozottságára, sokszínűségére utal.

Az empirikus kutatásokkal foglalkozó tanulmányok szerzői általában alacsony szinteken ábrázolták vizsgálataik főbb tartalmi csomópontjait. Csupán három alkalommal („kutatás folytatása”, „ismeretközvetítés Magyarországon”, "kutatási módszer") találtunk öt illetve hat szinten vizsgált alkódokat. A fokszámok is eltérőek a főkódok esetében. Léteznek magas fokszámú alkódok (kvalitatív kifejezés 19, trianguláció 15 alkód), viszont vannak nagyon alacsony fokszámú főkódok is (mintavétel szempontjai négy alkód, számítógéppel támogatott kvalitatív adatelemzés három alkód). Az elméleti cikkek tartalmi és szintszámbeli kiegyensúlyozottságával ellentétben, az empirikus kutatások eltérő hangsúlyt fektetnek a különböző kvalitatív módszertani témakörökre.

\section{A kvalitatív vizsgálatok elméleti hátterével foglalkozó tanulmányok}

A kvalitatív vizsgálatok elméleti hátterével foglalkozó publikációkat saját tapasztalataink alapján hat alkategóriába soroltuk, melyeket részletesen kifejtünk a továbbiakban: (a) a kvalitatív kutatás filozófiai hátterét bemutató tanulmányok; (b) a módszerek alkalmazhatóságával kapcsolatos írások; (c) a metodológiai elveket részletező cikkek; (d) a vizsgálatok sokszínű megközelíthetőségének problematikáját elemző tanulmányok; (e) a kvalitatív kutatás elveinek, felépítésének vizsgálatát célul kitűző tanulmányok; (f) kvalitatív elemzések struktúrája, elvi megközelítésével kapcsolatos cikkek.

A kvalitatív kutatások filozófiai hátterét érintő tanulmányok az Új Pedagógiai Szemlében (Bodrogi, 2011) és a Magyar Pedagógiában (Németh, 2015) találhatók. A módszerek alkalmazhatóságát három Iskolakultúrában megjelenő tanulmány tárgyalta ( Sántha, 2011, 2014, 2015), míg a metodológiai elveket kettő, szintén az Iskolakultúrában publikált cikk részletezte (Sántha, 2012a, 2012b). A vizsgálatok sokszínű megközelíthetőségének problematikájával az Iskolakultúra egy tanulmánya foglalkozott (Sántha, 2013). A kvalitatív kutatás elveivel, felépítésével kapcsolatban nem találtunk cikket. A kvalitatív elemzések struktúrájával, elvi megközelítésével az Is kolakultúrában megjelenő egyetlen tanulmány foglalkozott (Gyeszli és Sántha, 2015). A továbbiakban e tételeket részletezzük az alkategóriák függvényében.

A kvalitatív kutatás filozófiai hátterét elemző témakörben Bodrogi (2011) a kreativitásra építő élményközpontú irodalomtanítás hermeneutikai megközelítésével foglalkozik, említést tesz a hermeneutikai szövegértelmezésben rejlő lehetőségekről, az egyén olvasatain belüli különbségekről. Kiemeli a kulturális kontextus érvényét. Németh (2015) a neveléstudomány ismeretelméleti hátterét mutatja be, részletesen ír a hermeneutikáról és a fenomenológiáról. Ismerteti a humán tudományok önállósodási törekvéseinek folyamatát, említést tesz a kvanti- 
tatív és kvalitatív kutatásmódszertan egyenrangúságáról, tárgyalja az Európában és Amerikában lezajló tudományelméleti fordulatot, valamint a társadalomtudományok differenciálódásának folyamatát.

A módszerek alkalmazhatóságát érintő munkák esetén Sántha (2011) a fotóinterjút ismerteti, ez a technika teljesíti a módszertani trianguláció követelményeit, valamint fő- vagy almódszerként beépíthető a kombinált paradigma szerinti kutatásokba is (itt már láthatóvá válik a kevert módszertan fontosságát hangsúlyozó irányzat). A módszer során használt fotók, mint multikódolt adatok inter- és intrakódolása hozzájárul a személyi trianguláció megvalósításához is. A kódolt fotókommentárok kvalitatív tartalomelemzéssel, míg a fotók vizuális tartalomelemzéssel vizsgálhatóak. Szabolcs $(2012,2013)$ tanulmánya érdekes és hasznos leírás a narratívákról. A szerző három narratív szemléletű pedagóguskutatást ismertet, melyek a kezdő pedagógusok nézeteinek, reflektív gondolkodásának feltárásához köthetők. A kutatások rámutatnak a dialógusok kezdő pedagógusok nézeteinek formálásában betöltött szerepére, továbbá a kutatási lépések algoritmizálásával erős metodológiai alapot teremtenek a narratív vizsgálatok számára.

Szintén a hazai módszertani repertoár bővítése érdekében tárgyalja Sántha $(2014,2015)$ a Kvalitatív Komparatív Analízis (Qualitative Comparative Analysis - QCA) technikáját, amely átmenetet képez a kismintás kvalitatív vizsgálatok és a kvantitatív elemzések között, a Boole algebra elemeit használja a társadalmi jelenségek feltételeinek meghatározása során. Összetett módszertanról van szó, amely releváns a neveléstudományi elemzések számára is, hiszen képes az iskola világának összetettségét több perspektíva szerint vizsgálni. A tanulmányokból információt szerezhetünk a QCA-elemzések számára rendelkezésre álló különféle szoftverekről is (például fsQCA, Kirq, R Package QCA, Tosmana). Az érdeklődők a témakör aktualitásairól a www.compasss.org honlapról tájékozódhatnak.

A kvalitatív elemzéseknél a metodológiai elvek teljesítése, a különféle terminológia megjelenése (lásd például a klasszikus kvantitatív esetben alkalmazott, vagy speciálisan a kvalitatív elemzések számára létrehozott terminusok használatát) mindig központi problémaként jelentkezik. E sokszínű területbe kíván betekintést engedni Sántha (2012a) tanulmánya, amely a metodológiai elvek részletezésénél többek között kitér az adatok triangulációjára, valamint a trianguláció vagy kristályosítás problémájára. A szerző kiemeli, hogy a trianguláció egyértelmű használata hozzájárulhat a kvalitatív módszertan szisztematizálásához, továbbá ismerteti a geokódolás mechanizmusát, kiemeli a kvalitatív adatelemzésre alkalmas szoftverek (Atlas.ti, MAXQDA, NVivo) szerepét a geo-referenciák kiépítésében, részletezi a Google Earth és e szoftverek kapcsolatát. Ezen a ponton a nemzetközi kvalitatív módszertani trendekhez való igazodási szándék figyelhető meg, megjelenik a komplex módszertani környezet megteremtésének igénye is.

A metodológiai elvek esetén feltúnik a megbízhatóság és az érvényesség közötti kritériumok tárgyalása. Megismerhetjük a kvalitatív vizsgálat megbízhatóságának feltételeit, az intra- és interkódolást, a megbízhatósági mutatót két vagy több kódoló esetén (Cohen-kappa, illetve Fleiss-kappa, Krippendorff-alfa) (Sántha, 2012b). Mindezek kiemelt szempontok a kvalitatív kutatások szisztematizálási folyamatában, ennek megfelelően, a kvalitatív adatok elemzésére alkalmas szoftverek megfelelő funkciói is foglalkoznak a témával.

A vizsgálatok sokszínú megközelíthetőségének problematikáját elemző tanulmányokkal kapcsolatban megállapítható, hogy a közelmúlt évtizedeinek társadalomtudományi vizsgálataiban fokozatosan erősödött a kombinált paradigmát (Mixed Methods) fókuszba helyező irány. Sántha (2013) szerint a kombinált módszertannal biztosítható a vizsgálatok sokszínűsége, növelhető többek között a kutatások érvényessége és megbízhatósága is. A szerző elemzi a Mixed Methods és a módszertani trianguláció kapcsolatát, kitér a módszertani trianguláció változataira (Between Method/Across Method, Within Method), kiemeli, hogy a kombinált módszertani vizsgá- 
latoknál megjelenő multikódolt adatok szintén feldolgozhatók a kvalitatív adatok elemzésére alkalmas szoftverekkel.

A kvalitatív elemzések struktúrájával, elvi megközelítésével foglalkozó tanulmányok a vizsgálatok speciális megközelítéseinek rendszerét hivatottak feltárni. A vizsgált időszakban egy tanulmányt találtunk e témakörhöz tartozónak. Gyeszli és Sántha (2015) az Iskolakultúrában ismertették az általuk végzett kvalitatív elemzés struktúráját, speciális témában gondolkodtak, amikor az abduktív következtetés osztálytermi interakciókban való megjelenését vizsgálták. A kontextusfüggő jelleg miatt strukturálatlan megfigyeléssel dolgoztak. A szerzők az osztálytermi interakciók vizsgálatánál kiemelték a trianguláció-típusokat (módszertani, elméleti, személyi, adatok triangulációja), hangsúlyozták, hogy az adatok triangulációjából eredő problémák speciálisan az osztálytermi felvételek elemzésére szakosodott Videograph szoftver alkalmazásával oldhatók meg.

\section{Kvalitatív módszerek alkalmazhatóságát elemző tanulmányok (empirikus anyagok)}

A kvalitatív módszerek alkalmazhatóságát elemző empirikus publikációkat tapasztalatunk alapján négy alkategóriába soroltuk: (a) egy kvalitatív módszert alkalmazó empirikus cikkek; (b) két kvalitatív módszert alkalmazó empirikus cikkek; (c) kvalitatív és kvantitatív kombinációt (Mixed Methods) használó tanulmányok; (d) iskolafejlesztést, hatékonyságnövelést érintő témában megjelenő kvalitatív módszerek.

A négy kategóriát tekintve megállapítható, hogy hat tanulmány egy kvalitatív módszert ( Deutsch, 2011; Fülöp és Pressing, 2012; Hüse, 2011; Horváth, 2012; Molnár, 2012; Tóth, 2015), míg egy cikk kettőnél több kvalitatív módszert alkalmazott (Mészáros, 2011). Három tanulmány használt kvalitatív és kvantitatív kombinációt (Dorner és Konyha, 2015; Somogyvári, 2013, 2014), két cikk foglalkozott iskolafejlesztéssel, hatékonyságnöveléssel (Kovátsné, 2011; Lampert, 2011).

Az egy módszer alkalmazása esetén a kvalitatív empirikus tanulmányok tipikus problémájába ütközünk, mely szerint egy kvalitatív módszerrel általában nem biztosíthatók a speciális metodológiai követelmények (lásd módszertani trianguláció), célszerű több, ugyanazon probléma feltárására alkalmas technikát párosítani. Speciális esetben a Seidman-féle mélyinterjú, vagy a fotóinterjú alkalmazásával, a módszerek többszörösen összetett jellegének köszönhetően teljesíthető a módszertani trianguláció.

A főkódnál az interjú (félig strukturált, fókuszcsoportos, egyéni félig strukturált), nyílt kérdéses kérdőív, írásbeli kikérdezés, pedagógiai etnográfia (résztvevő megfigyelés, kutatási napló, interjú, kérdőív alkalmazásával) alkódok jelentek meg. A leggyakoribb módszer az interjú volt, csupán egy szerző indokolta részletesen a kvalita tív módszer választását (Molnár, 2012). Fülöp és Pressing (2012) a pedagógusok nézeteinek feltárására nyílt kérdésekből álló kérdőivet alkalmazott (itt elgondolkodtató a strukturált interjú terminológia megjelentetése is), Molnár (2012) pedig előzetes vizsgálati módszerként problémaérzékenyítésre használta a nyitott kérdésekkel történő írásbeli kikérdezést. A kutató megemlítette, hogy az érvényesség növelése érdekében további vizsgálati eszközöket tervez használni, ekkor feltünt a módszertani trianguláció és a speciális kvalitatív metodológiai elvek összekapcsolásának lehetősége is. Ez a gondolati struktúra a kvalitatív elemzések szisztematizálásához vezet, összhangban áll a nemzetközi törekvésekkel. Egy szerző részletesen kifejtette az egyéni félig strukturált interjú felvételének folyamatát, leírta az interjúprotokollt (Tóth, 2015). A szerzők nem tesznek említést arról, hogy mennyire alkalmasak az általuk használt kvalitatív módszerek a konkrét kutatási téma feltárására.

Tizenegy tanulmányból kilencben megjelent a "kvalitatív" kifejezés (Deutsch, 2011; Mészáros, 2011; Fülöp és Pressing, 2012; Horváth, 2012; Molnár, 2012; Somogyvári, 2013, 2014; Dornerés Konyha, 2015; Tóth, 2015). Az induktív kódolás alapján megállapítható, hogy további két tanulmányban is kvalitatív elemzést használtak a szer- 
zők annak ellenére, hogy a „kvalitatív” fogalmat nem említették (Hüse, 2011; Perényiné, 2011). Ezek a tanulmányok szintén a vizsgálat részét képezték.

A kvalitatív kifejezést hat alkódnál (kvalitatív tartalomelemzés, kvalitatív adatelemző szoftver, minta, az eredmények érvényessége, a vizsgálat korlátai, kvalitatív és kvantitatív módszereket ötvöző adatelemzés) találtuk meg. A szerzők leggyakrabban a kvalitatív tartalomelemzést említették, de csupán három tanulmánynál részletezték a kvalitatív tartalomelemzés folyamatát (Fülöp és Pressing, 2012; Dorner és Konyha, 2015; Tóth, 2015). Ez a probléma elgondolkodtató, hiszen a kvalitatív tartalomelemzés kifejezés önmagában kevés információval lát el a vizsgálat folyamatáról, a célokhoz illesztett kvalitatív tartalomelemzési tipológia egyértelmú jelölése adna megfelelő bizonyítékot a módszertani tudatosságról. Somogyvári (2014) a kvalitatív tartalomelemzést antropológiai megközelítésben képi szimbólumok elemzésére használta.

Kvalitatív adatok elemzésére alkalmas szoftverek alkalmazásáról három tanulmányban találtunk említést. Fülöp és Pressing (2012), valamint Tóth (2015) az Atlas.ti-t, Mészáros (2011) pedig az NVivo szoftvert használta kutatása során. Ebben a témakörben indokolt lenne a nemzetközi törekvésekhez történő gyorsabb felzárkózás a hazai kvalitatív neveléstudományi módszertan részéről.

A szerzők két esetben a mintánál említették, de nem részletezték a kvalitatív módszertan alkalmazását (Deutsch, 2011; Horváth, 2012). Molnár (2012) felhívta a figyelmet az érvényesség és a kvalitatív vizsgálat problematikájára. Tóth (2015) részletezte a kvalitatív vizsgálat korlátait, a leíró statisztikák készítésének nehézségeivel érvelt, aggályait a minta elemszámával és a mintavételi eljárással kapcsolatban fogalmazta meg. A szerző kiemelte a kvalitatív és a kvantitatív módszerek együttes alkalmazásának problémáit, azonban nem hangsúlyozta a kombinált módszertanban rejlő lehetőségeket. Feltűnő, hogy a kutatókban elsősorban a kvalitatív kutatással kapcsolatos problémák és kétségek merültek fel, az előnyökről, a pozitívumokról alig tettek említést.

A vizsgált 11 cikknél egyetlen esetben sem találtuk meg a trianguláció kifejezést, viszont 10 tanulmány tartalmaz olyan szövegrészeket, amelyek arról tanúskodnak, hogy a szerzők használták a trianguláció különböző típu sait. A tanulmányok többsége az adatok triangulációját alkalmazta, ritkán a módszertani trianguláció módszerek közötti változata is megjelent. Somogyvári (2014) indirekt megfigyelést végzett kvalitatív és kvantitatív tartalomelemzéssel, Mészáros (2011) a pedagógiai etnográfia módszereit kombinálta kérdőívvel. Dorner és Konyha (2015) kérdőívet vett fel és esetfeldolgozást végzett kvalitatív tartalomelemzéssel, a kvalitatív kutatási eszközöket interakciók kódolására használták. A módszeren belüli triangulációval összhangban Hüse (2011) fókuszcsoportos interjút és egyéni interjút használt. Perényiné(2011) projektív technikákat (rajztesztet és világjáték-tesztet) alkalmazott az érzelmek vizsgálatára. A személyi trianguláció egyértelműen Dorner és Konyha (2015) cikkében jelent meg, akik kiemelték, hogy két kutató bevonásával kvalitatív tartalomelemzést végeztek. Ebben az esetben az interkódolás a szisztematizálás felé történő elindulást mutatja. Egyes elemzők jól érzékelték a kvalitatív vizsgálat érvényessége körüli problematikát, de nem használták a probléma megoldására alkalmas trianguláció-tipológiák egyikét sem (Molnár, 2012).

A mintavétel szempontjai főkód négy cikkben jelent meg (Deutsch, 2011; Dorner és Konyha, 2015; Horváth, 2012; Tóth, 2015), csak egyetlen esetben találtunk hivatkozást a kvalitatív mintavételi stratégia alkalmazására (Deutsch, 2011). Mindez azt mutatja, hogy ez a tartalmi csomópont átgondolandó és fejlesztésre szorul a jövő hazai kvalitatív empirikus vizsgálatai számára.

A vizsgált időszakban két olyan cikket találtunk, amelyek kvalitatív módszereket említenek az iskolafejlesztés, a hatékonyságnövelés témakörében. A szerzők felsorolták a módszereket, de sajnos nem tértek ki alkalmazásuk szempontjaira. Lampert (2011) a természettudományos kompetenciák fejlesztésével foglalkozott a földtudományi ismeretek segítségével. A projekt ismertetésében a következő esetekben jelentek meg kvalitatív mód- 
szerek: a személyes célok megismerését elősegítő módszerek (hangosan gondolkodás, támogatott felidézés, fogalmi térkép), az önállóságot, kreativitást, kutatást előnyben részesítő technikák (megfigyelés, interjú, terepkutatás, esettanulmány). Kovátsné (2011) a környezeti nevelés hatékonyságának növeléséről írt a diákok gondolkodásmódjának és viselkedéskultúrájának fejlesztése által. A projekt célja a környezettudatos életvezetésre való felkészítés volt. A szerző szerint ez a jó gyakorlat iskolafejlesztő modell, amely alkalmas a komplex személyiségfejlesztésre. A modulokban kvalitatív módszerek (fogalomtérkép, rendezett fa, interjú, megfigyelés, dokumentumelemzés, hangosan gondolkodás) is megjelentek.

\section{A recenziók, tudományos konferencia-ismertetők}

A recenziókat három tartalmi kategória, a tartalomismertetés, a mértéktartó és az erős kritika alapján vizsgáltuk. Az Iskolakultúrában egy tartalomismertetés található az abdukció és a kvalitatív kutatásmódszertan lehetséges kapcsolatát tárgyaló kötetről (Di Blasio, 2012), továbbá a Pedagógusképzés is egy tartalomismertetést közölt egy az életutak javítóintézeti világát ismertető kötetről, amelyben a szerző átfogó kitekintést adott a kvalitatív kutatás elméleti hátteréről, vizsgálata során többféle módszert (résztvevő megfigyelés, szóbeli kikérdezés, fókuszcsoportos interjú) alkalmazott, az élettörténeteket interjúk segítségével tárta fel (Berényi, 2012-2013). Az Iskolakultúrában egy mértéktartó kritikát megfogalmazó recenzió jelent meg egy angol nyelvű kutatásmódszertani kötetről (Józan, 2012). Erős kritikát leíró recenziót egyetlen folyóiratban sem találtunk. Erős kritika alatt azokat a recenziókat értettük, amelyek a tartalomismertetésen túl többségében bírálatot, kedvezőtlen értékelést adnak az érintett müről.

A folyóiratokban két 2014-es nemzetközi tudományos konferenciáról (a CiCe-hálózat konferenciája és a nicosiai EARLI JURE konferencia) szóló ismertető is megjelent (Kinyó és Dancs, 2014; Török és mtsai., 2015), mindezek a kvalitatív módszertant alkalmazó kutatásokról is informáltak. Az EARLI JURE konferenciáról készült tudományos beszámoló szerint az előadások a kvantitatív és a kvalitatív megközelítések integrációjának szükségességét is kiemelték (Törökés mtsai., 2015).

\section{Összegzés}

A 2011 és 2015 közötti időszakban a vizsgált négy neveléstudományi folyóiratban csekély számban találtunk filozófiai hátteret bemutató írásokat annak ellenére, hogy a kvalitatív módszertant követőknek a filozófiai háttérrel, a valóság konstruálásával kapcsolatos nézetekkel egyaránt célszerű tisztában lenniük. Az eredmények alapján megállapítható, hogy a kvalitatív kutatásmódszertan elméleti hátterével foglalkozó tanulmányok sokoldalúak, a témakör sokszínűen kidolgozott, nem csupán kvalitatív módszertannal foglalkoztak, hanem kitértek a közeljövő ben valószínúleg itthon is egyre hangsúlyosabbá váló kombinált módszertani modellek illusztrálására is. A vizs gált időszakban kiemelt figyelem illette a kvalitatív kutatás érvényességi és megbízhatósági kritériumainak problematikáját is, több olyan elem (például, trianguláció, kódolás megbízhatósága) került elméleti és gyakorlati síkon is részletes bemutatásra, amelyek hozzájárultak e módszertani szegmensről alkotott kép tisztázásához. Továbbá a tanulmányokban hangsúlyos szerepet kapott a számítógéppel támogatott kvalitatív adatelemzés, ez a terület reményeink szerint a közeljövőben a hazai empirikus kvalitatív neveléstudományi kutatásokban egyre inkább elterjedhet.

A hazai kvalitatív pedagógiai kutatásmódszertan jelenlegi helyzetéről megállapítható, hogy az elmúlt több mint 15 év markáns változást hozott egyrészt a kvalitatív módszertan megítélésében, másrészt pedig a módszertan belső stabilitásában. Egyre több kutató tekinti úgy a kvalitatív paradigmát, mint amely alkalmas a rejtett, 
helyzetfüggő elemek feltárására, és a kvantitatív paradigmával közösen olyan újabb módszertani perspektívát nyithat meg, amely a kevert módszertanban realizálódhat. A belső stabilitás vonatkozásában nagy lépést tett előre a kvalitatív módszertan a szisztematizálási törekvések megvalósításával, lásd a kódolás megbízhatóságát, a többdimenzionalitás biztosítását vagy az egzakt kódolási mechanizmusok alkalmazását.

A 2011 és 2015 közötti időszakban a hazai kvalitatív módszertani törekvések - ha kissé lassan is, de - próbálták követni az aktuális nemzetközi irányzatokat. A nemzetközi trendek hazai kvalitatív módszertanban történő stabilizálása érdekében célszerű lenne itthon több szakmai fórumot, workshopot rendezni, hiszen az elmélet és a gyakorlat ötvözésével lehetünk kvalitatív kutatásmódszertani szempontból is felkészültek.

\section{Megjegyzés}

Sántha Kálmán kutatását az EFOP - 3.6.1. - 16 - 2016 - 00001 „Kutatási kapacitások és szolgáltatások komplex fejlesztése az Eszterházy Károly Egyetemen" pályázat támogatta.

\section{Szakirodalom}

1. Berényi Ildikó (2012-2013): Gyermeksorsok, életutak a javítóintézet világából. Pedagógusképzés, 39-40. 207-209.

2. Bodrogi Ferenc Máté (2011): Az irodalom, a kreativitás és a "nem-hermeneutikai". Új Pedagógiai Szemle, 11-12. 98-107.

3. Corbin, J. és Strauss, A. (2015): A kvalitatív kutatás alapjai. L'Harmattan Kiadó, Budapest.

4. Deutsch Krisztina (2011): Iskolai egészségfelfogás és egészségfejlesztés kvalitatív és kvantitatív kutatások tükrében. Új Pedagógiai Szemle, 1-5. 225-234.

5. Di Blasio Barbara (2012): Bizonytalanság vagy stabilitás? Iskolakultúra, 10. 126-131.

6. Dorner Helga és Konyha Rita (2015): Esettanulmány alapú online kollaboratív tudásépítés és vizsgálata a tudásépítő interakciók kapcsolatrendszere az elégedettséggel és az eredményességgel. Magyar Pedagógia, 3. 157-181.

7. Fülöp Márta és Pressing Zsuzsanna (2012): Pedagógusok nézetei az iskola szerepéről a versengésre és vállalkozásra való felkészítésben. Iskolakultúra, 3. 4-63.

8. Galántai László (2016): Rendszerszerű pályák. A sikeres egyetemi felvételi szocializációs előzményei a PTE Wlislocki Henrik Szakkollégiumában. Educatio, 3. 348-358.

9. Gyeszli Edit és Sántha Kálmán (2015): Abdukció az osztálytermi interakcióban. Iskolakultúra, 12.19-27.

10. Horváth József (2012): „A szakmai közösségnek tudnia kell ezekről a problémákról”. A plágium kezelése a magyar egyetemi gyakorlatban. Iskolakultúra, 7-8. 96-110.

11. Hüse Lajos (2011): Kettős mérce az iskola szerepének megítélésében - egy kirekesztéskutatás margójára. Iskolakultúra, 1. 88-98.

12. Józan Anna (2012): Az oktatáskutatás módszertana. Iskolakultúra, 11. 118-120.

13. Keller, R. (2014): Zukünfte der qualitativen Sozialforschung. Forum Qualitative Sozialforschung / Forum Qualitative Social Research, 15.1. URL: http://nbn-resolving.de/urn:nbn:de:0114-fqs1401165. Utolsó letöltés: 2016. március 25.

14. Kinyó László és Dancs Katinka (2014): Az identitás és állampolgárság kutatása Európában - beszámoló a CiCe-hálózat 2014-es konferenciájáról. Iskolakultúra, 10. 119-122.

15. Kovátsné Németh Mária (2011): Az Erdőpedagógia projekt a fenntarthatóságra nevelés életmódstratégiája. Új Pedagógiai Szemle, 1-5. 409-421.

16. Kuckartz, U. (2012): Qualitative Inhaltsanalyse. Methoden, Praxis, Computerunterstützung. Beltz Juventa, Weinheim und Basel. 
17. Lampert Bálint (2011): Környezetünk a Föld. A természettudományos kompetencia fejlesztése a földtudományi ismeretek segítségével. Új Pedagógiai Szemle, 1-5. 372-389.

18. Mészáros György (2011): Ifjúsági szubkultúrák és „szubkulturális pedagógia” egy iskolai etnográfia fényében. Iskolakultúra, 1. 22-38.

19. Molnár Melinda (2012): A pedagógiai irónia mint a pedagógiai hatalom kifejeződése. Iskolakultúra, 5. 24-36.

20. Németh András (2015): A neveléstudomány nemzetközi modelljei és tudományos irányzatai. Magyar Pedagógia, 3. 255-294.

21. Perényiné Somogyi Angéla (2011): A gyermekek környezeti attitűdjeinek vizsgálata projektív eljárásokkal. Új Pedagógiai Szemle, 1-5. 357-371.

22. Sántha Kálmán (2009): Körkép a hazai kvalitatív pedagógiai kutatásokról. Iskolakultúra, 5-6. 86-96.

23. Sántha Kálmán (2011): A fotóinterjú a pedagógiai architektúra vizsgálatában. Iskolakultúra, 4-5. 55-66.

24. Sántha Kálmán (2012a): Geo-információk a kvalitatív pedagógiai vizsgálatokban. Iskolakultúra, 11. 57-65.

25. Sántha Kálmán (2012b): Numerikus problémák a kvalitatív megbízhatósági mutatók meghatározásánál. Iskolakultúra, 3. 64-73.

26. Sántha Kálmán (2013): A harmadik paradigma a neveléstudományi vizsgálatokban. Iskolakultúra, 2. 82-91.

27. Sántha Kálmán (2014): Qualitative Comparative Analysis: Módszertani lehetőség a pedagógiai vizsgálatok számára. Iskolakultúra, 6. 3-16.

28. Sántha Kálmán (2015): Kvalitatív Komparatív Analízis a pedagógiai térábrázolásban. Iskolakultúra, 3. 3-14.

29. Sántha, Kálmán (2016): Qualitative Forschung in der ungarischen Erziehungswissenschaft zwischen 2000 und 2010. Eruditio-Educatio (közlésre elküldve).

30. Somogyvári Lajos (2013): Pedagógusképek és -szerepek az 1960-as évek Magyarországán, Magyar Pedagógia, 1. 29-52.

31. Somogyvári Lajos (2014): Az iskolán belüli és kívüli nevelés színterei az 1960-as évek Magyarországán beavatás az úttörőmozgalmi életbe. Iskolakultúra, 3. 51-59.

32. Szabolcs Éva (2012-2013): Narratív szemléletủ pedagóguskutatások. Pedagógusképzés, 39-40. 209-215.

33. Tóth Edit (2015): Az országos kompetenciamérés hatása a tanítási munkára pedagógusinterjúk alapján. Magyar Pedagógia, 2. 115-138.

34. Török Tímea, Thékes István, Asztalos Kata, Magyar Andrea és Kiss Renáta Mária (2015): A 2014-es nicosiai EARLI JURE konferencia. Iskolakultúra, 2. 82-88. 